\title{
The consumer production journey: marketing to consumers as co-producers in the sharing economy
}

\author{
Benedict G. C. Dellaert ${ }^{1,2}$ (D) \\ Received: 19 July 2017 / Accepted: 20 September 2018 / Published online: 4 October 2018 \\ (C) The Author(s) 2018
}

\begin{abstract}
New digital technologies not only support consumers in better fulfilling their own consumption needs but also enable them to create greater value for other consumers. These new consumer co-production activities, collectively referred to as the sharing economy, require firms to rethink their role in the marketing value creation process. Firms need to define new marketing actions that create value for consumers who are also co-producers. To address this challenge, we propose a two-layered conceptual framework of consumer co-production networks and the individual consumer production journeys therein. These concepts expand the traditional production model and consumer journey, respectively, explicitly taking into account consumer coproduction activities. Within the framework, we draw on household production theory combined with insights from institutional design theory and consumer behavior research to analyze how marketing can support consumers' co-production activities. We discuss the managerial and consumer welfare implications of our analysis and outline new opportunities for further research.
\end{abstract}

Keywords Consumer journey · Consumer co-production · Consumer co-production networks · Household production theory . Sharing economy

\section{Introduction}

With the uptake of digitization, technology is empowering consumers more than ever and putting them in charge of how they search, purchase, experience, and evaluate products (Labrecque et al. 2013; Simonson and Rosen 2014; Thaler and Tucker 2013). Over the next few decades, further advances in technology such as artificial intelligence, robotization, and 3D printing are predicted to enhance consumers' capabilities further still (Brynjolfsson and McAfee 2014; Kumar et al. 2016; Rust and Huang 2014). Importantly, these advances in digital technology not only support consumers in better fulfilling their own consumption needs but also enable them to produce

Rebecca Hamilton served as Special Issue Editor for this article.

Benedict G. C. Dellaert

dellaert@ese.eur.nl

1 Marketing Section, Erasmus School of Economics, Erasmus University Rotterdam, P.O. Box 1738, 3000

DR Rotterdam, The Netherlands

2 Department of Marketing, Monash Business School, Monash University, P.O. Box 197, Caulfield East, Victoria 3145, Australia new value for other consumers (Grönroos and Voima 2013; Ritzer and Jurgenson 2010; Telles 2016).

Furthermore, digitization also allows for restructuring and disintermediation in supply chains. Thus, it supports new collaborative structures and business models that incorporate consumers as active co-producers in the value creation process (Bloom et al. 2014; Botsman and Rogers 2010; Lusch and Nambisan 2015; Sundararajan 2016). For example, online retail platforms such as Etsy are empowering consumers to directly sell their self-created products to other consumers, firms such as Airbnb and Uber are allowing consumers to directly produce value for other consumers by using their own homes and cars, and review websites such as Yelp are boosting the impact of consumers' opinions on other consumers' purchase decisions. These new business initiatives involving consumer co-production through online platforms are often collectively referred to as the sharing economy (Hamari et al. 2016; Narasimhan et al. 2018; Schor and AttwoodCharles 2017; Sundararajan 2016).

In the sharing economy, value creation activities are undertaken partly by consumers and partly by firms. While research on household production theory traditionally has already underlined the active role of consumers in creating value for themselves and their direct circle of family and friends (Becker 1965; Da et al. 2015; Greenwood et al. 2005; Muth 
1966), the prominent shift that arises in the sharing economy is that now other consumers also benefit from consumers' coproduction activities and often through commercial transactions on online platforms (Frenken and Schor 2017; Narasimhan et al. 2018; Sundararajan 2016; Telles 2016). Connections typically occur between many consumers and firms that operate together in networks where each takes on different production activities (Achrol and Kotler 2012; Scaraboto 2015; Vargo and Lusch 2016). To reflect the fact that consumers themselves are also important value co-producers along with firms, we refer to these new platform-based collaborative structures as consumer coproduction networks.

The emergence of consumer co-production networks puts the traditional strengths of manufacturers and service firms under pressure and creates new challenges for marketing. In particular, marketing-oriented firms need to find new ways to create value for consumers to maintain a sustainable competitive advantage (Achrol and Kotler 2012; McAfee and Brynjolfsson 2017; Muniz and Schau 2011). By creating greater value for consumers, firms can sustain long-term relationships with their customers. These relationships safeguard the customer access needed to generate profits and represent a marketing resource that is hard to copy for competitors. Thus, consumer value creation strengthens the firm's competitive position (Hunt and Morgan 1995; Kozlenkova et al. 2014; Wernerfelt 2014).

We propose that in consumer co-production networks, marketing should increasingly focus on developing new functions that can support consumers who are also active as coproducers (Piskorski 2011; Ranjan and Read 2016; Ritzer and Jurgenson 2010). More specifically, we develop a framework for analyzing how firms can assist consumers who are also themselves becoming producers of value. This framework consists of two layers, one at the network level and one at the individual consumer level. The layers expand the traditional production model and consumer journey, respectively, to explicitly take into account consumer co-production activities. Within this framework, we expand household production theory with insights from institutional design theory and consumer behavior research, to analyze how marketing functions can support consumers in their co-production activities in each layer. This approach allows us to propose specific opportunities for consumer-based marketing strategies that focus on the consumer's new role in the sharing economy (Hamilton 2016).

At the individual consumer level, marketing can create value in a consumer co-production network by assisting individual consumers in different steps of their co-production process. To analyze the potential for marketing value creation in this process, we introduce the consumer production journey. The consumer production journey describes the consumer's co-production process rather than the traditional consumption process and expands the consumer journey concept to explicitly take into account the fact that consumers create value for other consumers. Thus, this new concept allows us to connect consumer co-production in various stages of the value chain (e.g., peer-to-peer sales, service production, consumer reviews). At the individual level, we draw on household production theory to investigate how marketing can improve the costs and benefits that co-production brings to consumers (Becker 1965; Lancaster 1966; Priem 2007). We propose a broad concept of utility that extends normative utility with components from consumer behavior research.

Most importantly, we allow for the labor component of household production to have a positive valuation of production activities, for example, due to enjoyment of the activity and greater perceived autonomy (Buechel and Janiszewski 2014; Fuchs et al. 2010; Mathwick and Mosteller 2017). At the network level, we analyze marketing value creation opportunities when consumer production journeys are combined and integrated into networks involving multiple consumers. This analysis focuses on marketing activities that can increase consumers' collective payoff (over and above the support that can be given to each consumer individually) and addresses the challenges consumers face when making the transition to consumer co-production networks from more traditional marketing arrangements (Carson et al. 1999; Wernerfelt 1994). Finally, we discuss the proposed framework's management implications and critically review the consumer welfare implications of consumer co-production networks. We close with a discussion of some limitations of our analysis and opportunities for future research.

\section{Consumer co-production networks in the sharing economy}

\section{Defining the sharing economy}

The literature on sharing economy systems has placed different emphases on what types of consumer co-production activities are seen as part of the sharing economy. In particular, research has varied in how restrictively sharing economy systems are defined. Most definitions in the literature can be classified along two lines: (1) definitions that include only noncommercial sharing versus those that include both commercial and noncommercial sharing and (2) definitions that include only the sharing of capital goods versus those that also include consumer co-production of services along with capital goods.

Early on, several authors emphasized noncommercial variants of sharing economy systems (Belk 2007, 2010; Benkler 2002; Botsman and Rogers 2010; Thomas et al. 2013). These authors highlighted the potential of sharing capital goods and the provision of peer labor by consumers as an alternative to traditional market economy-based value creation models. 
Typical, noncommercial examples of sharing include activities such as the development of open-source software (e.g., Linux) and the (unpaid) neighborhood sharing of equipment and skills (e.g., streetbank.com) or residential spaces (e.g., couchsurfing.com). More recently, other authors have also recognized the role of commercial transactions in sharing economy systems (Sundararajan 2016; Zervas et al. 2017). These commercial systems are still such that consumers are actively producing value for other consumers, but the consumer value exchanges are facilitated by online commercial platforms where both firms and consumers can be active in commercial activities. For example, peerby.com introduced a peerto-peer renting opportunity for equipment on their platform, and Airbnb offers a hugely successful commercial exchange of residential spaces for travelers.

Regarding the second line of distinction, some researchers (Frenken and Schor 2017; Jiang and Tian 2016) have focused their definition of the sharing economy exclusively on capital good sharing, for example, Airbnb, where consumers share their home. However, others have developed a broader conceptualization of the sharing economy that allows for a wider range of consumer co-production activities that also include consumer services, for example, Uber, where consumers use their car to offer the service of driving others to certain destinations (Narasimhan et al. 2018; Sundararajan 2016). Within this latter research stream, a number of authors have also highlighted the role of digital technology and online matching platforms as key facilitators of the co-production of goods and services by consumers (Evans and Schmalensee 2016; Gansky 2010; Telles 2016).

We adhere to the broader definition of the sharing economy. In line with Sundararajan (2016), we define consumer coproduction networks as value creation systems in which part of the capital goods and services are provided by individual consumers rather than firms, including consumer co-production that is provided for a commercial purpose. Consequently, the lines between personal and professional activities, leisure and work, and the independent and dependent employment of the individuals participating in the value creation systems are blurred. In line with the commercial perspective on the sharing economy, we address those networks that are facilitated by digital technology provided by a firm, such as online matching platforms (Sundararajan 2016; Telles 2016).

\section{Consumer co-production networks}

Within the sharing economy, consumer co-production networks bring together consumers and firms to take on different production activities in the value chain. To more precisely define these networks, we introduce two conceptual dimensions that capture the role of consumers as co-producers in the value creation process. The first dimension describes the extent to which consumers are active as co-producers in the value creation process. This dimension highlights the difference between the low level of consumer co-production in traditional consumption activities (e.g., taking a taxi or eating in a restaurant) versus the high level of consumer coproduction in sharing economy-oriented activities (e.g., driving for Lyft or sharing a homemade meal with others through Shmeal). The transition from a low to a high level of consumer co-production activity is facilitated by digital technology that, for example, supports direct online interactions between consumers and firms and allows consumers to take control of different aspects of the production process, such as when they use $3 \mathrm{D}$ printing technology to produce consumer products in their own home.

The second dimension describes the unit level at which consumer co-production activity takes place. It distinguishes between consumer co-production that takes place at the individual level (individual-level co-production) ${ }^{1}$ and coproduction that takes place at the network level and in which multiple consumers collaborate (network-level coproduction). This second dimension is also facilitated by digital technology, for example, when it supports complex communications and transactions between multiple agents in the value creation process or large-scale data analytics that combine market-level insights across multiple consumers.

Together the two dimensions represent four prototypical value creation models with various degrees of consumer coproduction in the value creations process (see Fig. 1). Within this framework, the consumer co-production network model arises if the extent of consumer co-production is high and it also takes place at the network level. Note that, since the proposed dimensions are continuous, the transitions between these value creation models are fluid and gradual. For example, for a consumer activity such as dining, the extent dimension of consumer co-production includes a wide range of levels even for a single individual. These levels can vary from none at all (when eating in a restaurant), to minor coproduction (when heating a pre-cooked meal both in a store), and full co-production (when preparing one's own meal from scratch). While, later, we focus on consumer co-production networks only, here we first describe the resulting framework in more detail and relate it to earlier research. Table 1 provides a summary of recent empirical examples from the marketing literature. We further illustrate the framework with real-world examples from the personal transportation market that also reflect the continuous nature of the proposed framework's underlying dimensions (see Fig. 2).

\footnotetext{
${ }^{1}$ For brevity, we speak of individual-level consumption, although this level also includes consumption by the consumer's close circle of family and friends (e.g., when family members purchase groceries for their household).
} 
Fig. 1 Consumer co-production framework: from traditional production to consumer coproduction networks

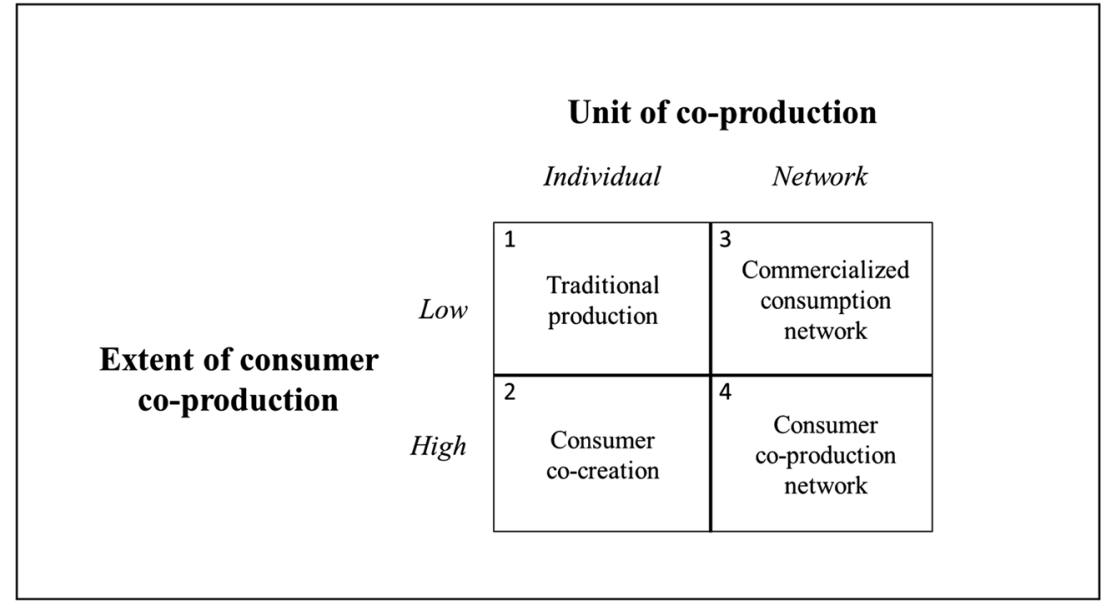

The first, upper left quadrant (low extent, individual-level co-production) of the framework represents the traditional production model in which the consumer and producer roles are clearly separate. In this model, manufacturers, retailers, and services providers take on the vast majority of the production activities and consumers consume. As personal transportation examples for this first value creation model, consumers can use a taxi service or rely on public transport. The extent of consumer co-production shifts when going from a taxi service to using public transport, as is reflected in position of these options in Fig. 2.

The second, lower left quadrant (high extent, individuallevel co-production) represents value creation systems where the consumer is actively involved in co-production activities but these activities do not benefit others. We refer to this as the consumer co-creation model. In this value creation model, consumers and firms work together interactively to create value, but only for each consumer him- or herself. Digital technology has allowed for more flexible interactions between consumers and firms compared to what was previously possible and this shift has generated new product access models (Bardhi and Eckhardt 2012) and co-production processes that benefit consumers individually (Etgar 2008; Payne et al. 2008; Prahalad and Ramaswamy 2004). In particular, co-production processes in which consumers are empowered to design their own products online have led to innovations in how consumers interact with a firm's production process (Dellaert and Stremersch 2005; Franke et al. 2010; Hildebrand et al. 2014). Research has shown that, depending on the extent of consumer input and the design of the consumer-firm interaction process, consumer evaluations of the co-created product can differ (Buechel and Janiszewski 2014; Mochon et al. 2012). Personal transportation examples are the option for consumers to drive a car from a car-sharing system such as Zipcar and the use of their own car to drive to their destination. In both instances, consumers are active as producers, but mainly to their own benefit. Examples of consumer co- creation in other domains include consumers' customization of their own shoes on NikeID or of their new car on a manufacturer's website, such as Audi's.

In the third, upper right quadrant (low extent, network-level co-production) are those production processes that do not require consumers to play an active role as co-producers but which create additional consumer value by integrating the consumption activities of multiple consumers at the same time. We refer to this as the commercialized consumption network model. This model is also facilitated by digital innovation and draws on the collective use of consumer data. Even passive consumers who do not provide labor or capital goods in the production process can still bring considerable value to other consumers if they are willing to provide access to their data, such as their relevant personal and sales data (Acquisti et al. 2016; Chung et al. 2016; Evans 2017; Goldfarb and Tucker 2011; Tucker 2014). For example, simply by agreeing to allow a search engine or an online retailer to trace what they search for online, consumers provide valuable data that can be used to provide recommendations to other consumers. The reason we refer to this model as the commercialized consumption model is that the consumer only needs to consume but firms can still commercialize the consumer's consumption activities. In a digitized setting, firms can generate valuable analytics for other consumers using each consumer's (passively provided) data as input. In personal transportation, this is the case when consumers are able to benefit from traffic information from other consumers who allow their travel information to be shared through an online system that helps optimize the driver's travel route. Google Traffic is an example of such a service that relies on drivers sharing their driving information but which does not require consumers to be actively sharing their cars or to operate as a driver for other consumers. Waze represents a similar service, but one where consumers are slightly more actively involved. Well-known examples in another domain are Netflix and Spotify, who leverage consumers' viewing and listening behavior to provide better recommendations to other consumers. 
Table 1 Examples of marketing studies classified according to the proposed framework

\begin{tabular}{|c|c|c|c|}
\hline Authors & Consumer activity & Research method & Main findings \\
\hline \multicolumn{4}{|l|}{ Consumer co-creation } \\
\hline Atakan et al. (2014) & $\begin{array}{l}\text { Design; Produce } \\
\text { products }\end{array}$ & Lab-experiments & $\begin{array}{l}\text { Consumer participation in the design or physical production of } \\
\text { products leads to greater affective commitment, which in turn } \\
\text { enhances evaluation of the product. }\end{array}$ \\
\hline $\begin{array}{l}\text { Bardhi and Eckhardt } \\
\text { (2012) }\end{array}$ & Distribute products & Interviews & $\begin{array}{l}\text { Consumers avoid identification with the object of consumption. } \\
\text { Their focus in the object-self relationship is use value. Shared use } \\
\text { is guided by norms of negative reciprocity. Consumers resist } \\
\text { efforts for community building. }\end{array}$ \\
\hline $\begin{array}{l}\text { Buechel and Janiszewski } \\
\text { (2014) }\end{array}$ & Assemble products & Lab-experiments & $\begin{array}{l}\text { When customization decisions and assembly processes are } \\
\text { segregated, assembly effort is unattractive. However, when the } \\
\text { processes are integrated, consumers are creatively engaged, and } \\
\text { value of the task and resulting product more highly. }\end{array}$ \\
\hline Franke et al. (2010) & Design products & $\begin{array}{l}\text { Interviews; } \\
\text { Lab-experiments }\end{array}$ & $\begin{array}{l}\text { Consumers have a higher willingness to pay for self-designed } \\
\text { products. This effect is mediated by feelings of accomplishment } \\
\text { and moderated by outcome and perceived contribution. }\end{array}$ \\
\hline Hildebrand et al. (2014) & $\begin{array}{l}\text { Design; Purchase } \\
\text { products }\end{array}$ & $\begin{array}{l}\text { Lab- and } \\
\text { field-experiments }\end{array}$ & $\begin{array}{l}\text { Presenting consumers with a product as a start for customization } \\
\text { increases their choice satisfaction, lowers perceived choice } \\
\text { complexity, and leads to purchases of more feature-rich products. }\end{array}$ \\
\hline Mochon et al. (2012) & Assemble products & Lab-experiments & $\begin{array}{l}\text { The feelings of competence that arise from assembling products } \\
\text { mediate the increased value of these products to consumers. }\end{array}$ \\
\hline
\end{tabular}

Commercialized consumption network

$\begin{array}{lll}\text { Chung et al. (2016) } & \text { Share data } & \text { Field studies } \\ \begin{array}{l}\text { Goldfarb and Tucker } \\ \text { (2011) }\end{array} & \text { Share data } & \begin{array}{c}\text { Survey with field } \\ \text { data }\end{array}\end{array}$

Tucker (2014) Share data $\quad$ Field experiment
Personalization using an algorithm results in better performance than allowing consumers to self-customize. Including data on consumers' social network improves personalization.

Display advertising became less effective in changing consumers' stated purchase intent after EU privacy laws were enacted compared to other countries without these laws.

After giving users greater control over the personal information shared through a website and how third parties could track their movements, users were nearly twice as likely to react positively to personalized ad content and to click on personalized ads.

Consumer co-production network

$\begin{array}{lll}\text { Brodie et al. (2013) } & \begin{array}{c}\text { Develop, Promote } \\ \text { products }\end{array} & \text { Netnography } \\ \begin{array}{l}\text { Chu and Manchanda } \\ (2016)\end{array} & \text { Sell products } & \text { Field study } \\ \begin{array}{l}\text { Fraiberger and } \\ \text { Sundararajan (2017) }\end{array} & \text { Rent out products } & \begin{array}{c}\text { Field study and } \\ \text { survey }\end{array}\end{array}$

Franke et al. (2006) Innovate products Survey

$\begin{array}{lll}\begin{array}{l}\text { Mathwick and Mosteller } \\ \text { (2017) }\end{array} & \text { Review products } & \text { Survey } \\ \text { Scaraboto (2015) } & \begin{array}{c}\text { Develop, Reflect } \\ \text { on products }\end{array} & \begin{array}{c}\text { Etnography; } \\ \text { Netnography }\end{array}\end{array}$

Stephen and Toubia $\quad$ Sell products $\quad$ Field study (2010)
Engaged consumers exhibit enhanced consumer loyalty, satisfaction, empowerment, connection, emotional bonding, trust and commitment.

The installed base of buyers vs. sellers of a platform drives growth of the other side. This effect is asymmetric and the installed base of sellers has a larger effect on buyers than vice versa.

Peer-to-peer rental markets improve consumer welfare. Surplus grows with access to the marketplace. Below-median income consumers constitute a higher fraction of peer-to-peer demand.

Consumers' own expected-benefits and the degree to which they are ahead of trends predict both their innovation likelihood and the commercial attractiveness of their user-developed innovations.

Consumers who review products all have altruistic motives. They differ in terms of egoistic motives: Some look for self-expression, others enjoy the experience, and others see it as a game to master.

Multiple modes and logics of exchange may successfully coexist in a collaborative network. Consumer-producer engagements in collaborative activities and the reconfiguring of socio-technical agencements sustain the network.

Allowing sellers to connect in a network generates value. This value comes from the sellers more accessible to buyers. 
Table 1 (continued)

\begin{tabular}{lccc}
\hline Authors & Consumer activity & Research method & Main findings \\
\hline Thomas et al. (2013) & $\begin{array}{c}\text { Experience, Reflect } \\
\text { on products }\end{array}$ & $\begin{array}{c}\text { Interviews; } \\
\text { Observation }\end{array}$ & $\begin{array}{l}\text { Sellers who benefit most are those whose accessibility enhanced } \\
\text { the most. } \\
\text { Despite heterogeneity, networks are can be stable when members } \\
\text { depend on each other for social and economic resources which } \\
\text { motivate them to collaborate and adopt frame alignment } \\
\text { practices. }\end{array}$ \\
Zervas et al. (2017) & Rent out products & Field study & $\begin{array}{l}\text { Consumer-supplied bedrooms lower hotel room prices, especially } \\
\text { during periods of peak demand and for non-business hotels. One } \\
\text { reason is that consumer supply can more flexibly scale to } \\
\text { demand. }\end{array}$ \\
\hline
\end{tabular}

This brings us to the fourth and final, lower right quadrant (high extent, network-level co-production), which represents the case in which the consumer's active involvement as a coproducer benefits other consumers. We refer to this case as the consumer co-production network model and it is most typical for many well-known examples in the sharing economy (Humphreys and Grayson 2008; Sundararajan 2016; Telles 2016). More formally, a consumer co-production network can be defined as a system of multiple consumers and firms that actively collaborate to fulfill a certain consumer need, often involving commercial interactions. Digital technology is an important enabler of this value creation model because it supports disentangling complex value creation systems into smaller activities and a rapid and accurate matching of the supply and demand of these activities across many different consumers and firm(s) participating in the system. A personal transportation example of an online platform that fits within this model is BlaBlaCar, a firm that allows consumers to coordinate long-distance ridesharing when they need to go to the same destination. Uber is another example of the consumer co-production network model. There, consumers are even more actively involved in co-production, since they operate as drivers for other consumers using their own car, even when they themselves do not need to go to a given location.
Similarly, Airbnb is a well-known example of an online platform-based firm that supports consumers as co-producers in the hospitality sector.

\section{The consumer production journey}

To provide further depth to our understanding of the consumer role in consumer co-production networks, we now develop a more detailed conceptualization of the different ways in which individual consumers can be involved in the co-production process. We refer to this process as the consumer production journey. To bridge between the traditional production model and the newly proposed consumer co-production network model, our conceptualization starts from the consumer decision making journey in a traditional consumption setting. The consumer decision making steps we distinguish are: (1) search, (2) purchase, (3) experience, and (4) reflect (see Table 2). These steps match well with the broader marketing literature on consumer journeys, where similar generic steps have been proposed of consumers first exploring and investigating a product, then purchasing a product, next consuming the product, and, finally, reflecting on the product and consumption experience (Anderl et al. 2016; Li and Kannan 2014; Norton and Pine 2013; Wiesel et al. 2011).
Fig. 2 Real-world examples of proposed framework for personal transportation

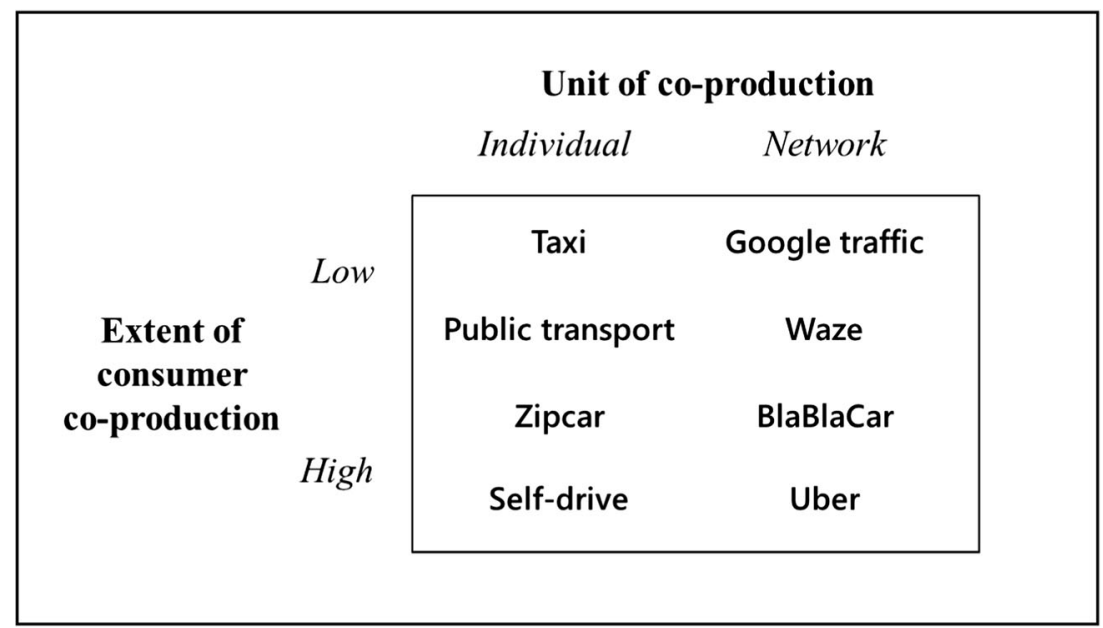


Table 2 The consumer production journey: the consumer role in traditional production versus a consumer co-production network

\begin{tabular}{lll}
\hline & Consumer role & \\
\cline { 2 - 3 } Journey step & Traditional production & Consumer co-production network \\
\hline 1. Search & Explore the market and one's own needs & Co-design and recommend products \\
2. Purchase & Buy products & Participate in distribution and sales of products \\
3. Experience & Consumption experience & Co-produce and share experiences \\
4. Reflect & Reflect on and care for products & Offer peer support, review, and innovate \\
\hline
\end{tabular}

In the first step of the traditional consumer journey, consumers search the market for products to satisfy their (latent) consumption needs. Thus, the consumer's traditional decision tasks are to search for information and to predict the level of consumption utility different products will provide them upon consumption. In the consumer production journey, the consumer role shifts and consumers take on part of the firm's traditional production role, for example, by actively promoting brands and approaching new consumers (Kumar et al. 2010). Consumers who are further advanced in understanding other consumers' product needs and the product innovations that best respond to such needs can also provide recommendations and co-design new product options for other consumers (Franke and Piller 2004; von Hippel 1986). For example, an online platform such as Threadless supports consumer design of T-shirts for other consumers.

Next, in the second step of the traditional consumer journey, consumers purchase the goods and services that they prefer for their consumption experience. From a decision making perspective, the consumer's task traditionally is to compare between various products available in the market that appear suitable for consumption and then decide on the most attractive alternatives to purchase. When consumers become active as co-producers, they themselves become sellers and distributors. For example, consumers can engage in social commerce and sell or distribute products through online platforms such as eBay and Etsy (Stephen and Toubia 2010).

The third step in the traditional consumer journey represents the actual consumption experience. In this step, consumers use goods and services to generate experienced consumption utility. When consumers are active as producers in the consumption step, they co-produce experiences for other consumers. Consumers can be actively involved in sharing their capital goods with others, for example, when driving their own car to transport other consumers, such as with Uber, or when sharing their home with tourists through Airbnb (Zervas et al. 2017).

Finally, the fourth step in the traditional consumer journey involves reflection on the consumption experience. Consumers typically evaluate the quality of their consumption and could undertake actions to improve or adjust their experiences. From a consumer decision making perspective, this evaluation can be an important input for subsequent consumption decisions
(Wirtz et al. 2003). When they become co-producers, consumers assume part of these activities for other consumers. For example, consumers review their consumption experiences to the benefit of other consumers on online platforms such as Yelp or they provide input in online peer-to-peer consumer support networks (Mathwick et al. 2008).

When considering the four steps in the consumer production journey in conjunction, there can be partial reiterations between the subsequent steps. As many events are multidimensional and repetitive (e.g., cooking a daily dinner), the different steps are likely to be experientially connected. Notwithstanding this interconnectedness, conceptually distinguishing the different steps helps marketers to examine the different consumer activities, evaluation processes, levels of expertise, and levels of engagement that are specific for each step.

\section{Marketing to consumers as co-producers: the individual-level perspective}

We adopt an institutional design perspective on marketing value systems to analyze how firms can provide marketing value for consumers who are co-producers (Carson et al. 1999; Vargo and Lusch 2016). A marketing value system design (hereafter "marketing design") comprises the total set of activities (e.g., distribution), agents (e.g., consumers and firms), and institutional arrangements (e.g., contracts) used to fulfill a certain consumer need. The remediable efficiency criterion for marketing design was developed within institutional design theory and provides a strong basis for our analysis (Carson et al. 1999; Wernerfelt 1994). The criterion proposes that those marketing designs that maximize the joint payoff across all agents involved in a marketing value system are most likely to survive in the market in the long term (under certain conditions of feasibility). For example, from the consumer perspective, a new car-sharing system may or may not remediably efficient, depending on if it can generate greater total consumption utility and income for the consumers participating in the new system (as passengers or drivers), in comparison to other transportation options already available to them. In our analysis we focus on the consumer perspective on the payoff of consumer co-production networks. We 
address how marketing can increase this payoff at the individual consumer level (this section) as well as at the network level (the following section). Managerial implications of our analysis are in the discussion section.

At the individual level, consumers face various trade-offs when they become co-producers in the value creation process. Household production theory offers a framework in which to analyze consumers' consumption decisions from an economic perspective (Becker 1965; Lancaster 1966; Muth 1966; Priem 2007). It has been previously applied to analyze marketingrelated topics such as consumers' use of retail formats (Betancourt and Gautschi 1990), the impact of new electrical household appliances on female labor force participation (Greenwood et al. 2005), and consumers' accumulation of product and consumption knowledge (Luo et al. 2013; Ratchford 2001). The theory highlights the fact that consumers use products and their own (unpaid) labor to generate consumption experiences. It suggests that one can think of consumption decisions as an optimization process in which consumers allocate scarce time and monetary resources to different products and activities so that these resources generate the highest possible utility outcome. Traditional household production theory explains, for example, that consumers buy electronic appliances such as dishwashers or laundry machines if these save time that can be more effectively spent performing paid labor or more pleasantly on leisure activities that provide greater utility than if the money were spent otherwise.

We build on household production theory to investigate consumers' individual payoff in consumer co-production networks. This approach fits well with the notion of consumer payoff in institutional design theory, while still allowing for refinements in terms of incorporating behavioral drivers of consumers' decisions. In its original formulation, household production theory provides three main components that marketing can target to create greater consumer value related to consumption (see Table 3): (1) increasing consumers' utility derived from goods and services, such as by enriching the consumption experience; (2) increasing the effectiveness of consumers' time budget spending, such as by increasing the convenience of making product purchases; and (3) increasing the effectiveness of consumers' money budget spending, for instance, by lowering the prices of some products to free up budget for other spending. For each of these three components, major shifts occur when consumers become coproducers and all three open up new opportunities and challenges for marketing.

\section{Increasing consumers' utility in co-production activities}

Concerning consumers' utility, traditionally, marketing can increase value for consumers by matching products as closely as possible to their needs. Much of marketing's activities are aimed at effectively meeting heterogeneity in consumer demand to maximize consumer utility. The closer a product matches consumer needs in a specific consumption situation, the greater its value for the consumer. A related objective of marketing is to increase consumers' utility by intensifying the utility they obtain per hour spent, for example, by meeting multiple consumption needs at the same time or by improving the consumer experience (Pine and Gilmore 1998; Schmitt 2011).

When we extend this perspective to co-production-oriented consumer activities, we find that marketing can play a similar role in co-production as in the traditional consumer journey, but focused on increasing the utility of the coproduction activity. Most similarly, as in the case of consumption, marketing can help consumers by improving products and co-production processes so that they are more closely in line with consumers' preferences. However, in addition, marketing can make activities that are traditionally seen as unattractive and production oriented more attractive and engaging for consumers. If the activities are well designed, individuals often place a higher value on their labor activities than just the payment they receive, and marketing can help increase the utility that consumers derive from a co-production activity itself. In particular, consumers can enjoy the creativity involved in co-designing new products, appreciate the feeling of empowerment that co-production brings, and value the social interaction and public recognition benefits of coproduction (Buechel and Janiszewski 2014; Fuchs et al.

Table 3 Marketing to consumers as co-producers: Individual-level perspective

\begin{tabular}{|c|c|c|c|}
\hline \multirow{2}{*}{$\begin{array}{l}\text { Household production } \\
\text { theory component }\end{array}$} & \multirow[b]{2}{*}{ Marketing action } & \multicolumn{2}{|l|}{ Consumers' improved outcome } \\
\hline & & Traditional consumption & Consumer co-production network \\
\hline Utility & Increase fit of product and consumer needs & Greater consumption utility & Positive utility from co-production process \\
\hline \multirow[t]{2}{*}{ Time budget (labor) } & $\begin{array}{l}\text { Increase fit of channel, product, and } \\
\text { consumer needs }\end{array}$ & Greater consumption convenience & Lower co-production effort \\
\hline & Promote individual transformation & Greater consumption skills & Greater co-production skills \\
\hline Monetary budget & Increase consumer surplus & Lower price & Commercial gains from co-production \\
\hline
\end{tabular}


2010; Mathwick and Mosteller 2017). Thus, a potential consumer benefit of co-production that marketing can strengthen is consumers' enjoyment of the process of co-production itself. For example, a firm such as Airbnb provides an online environment in which hosts and guests can socially interact before and after their stay and suggests to potential hosts that they will not only make extra money when they rent out their home, but also (and especially) have great experiences interacting with their guests.

Another key role of marketing is to find and activate expert and engaged consumers to become co-producers for each of the different steps in the consumer production journey. This is important for two reasons: first, because those consumers are most likely to enjoy the co-production process itself and, second, because they are most likely to create greater value for other consumers. In the search step, firms often do not have the knowledge, ability, or incentives to differentiate and distribute their supply according to individual customers' needs, but some (lead user) consumers may still be able to predict other consumers' needs and see how these other consumers can benefit from an improved product (Franke et al. 2006; von Hippel 1994). Similarly, in the purchase step, consumers who are knowledgeable about a product and see its potential value for other consumers are likely to be successful at distributing or selling this product to those other consumers. In the experience and reflect steps, activating consumers with expertise and engagement is also relevant. Selecting and activating consumers who are more likely to be effective at improving other consumers' experiences or at providing valuable feedback or peer-to-peer support to other consumers can create greater utility for other consumers (Brodie et al. 2013; Kumar et al. 2010; Mathwick and Mosteller 2017).

\section{Improving consumers' time budget spending in co-production activities}

When we first consider consumers' time budget in the context of consumption, marketing has traditionally placed great emphasis on creating convenience for consumers by offering new products and channels that help lower the amount of labor involved in purchasing and using products (e.g., by developing retail channels and providing ready-made products in food preparation or by developing media technologies to bring entertainment into the consumer home). These marketing innovations have greatly improved consumer welfare by lowering their personal labor costs related to consumption (Bronnenberg 2015). A second, traditional labor-related marketing role is that of enhancing and guiding consumers' consumption skills, for example, through advertising or training (John 1999; Luo et al. 2013), or, in other words, assisting consumers in a transformational learning process that creates greater value for the individual over time (Pine and Gilmore 1998).
With respect to the consumer production journey, in the search and purchase steps, the marketing function of online platforms can assist consumers in making their production activities more accessible to others (Stephen and Toubia 2010). Firms such as Amazon and Etsy provide extensive support services to facilitate and teach consumers who are active as sellers on their online platform. Increasingly, other (non-platform) firms are catering to consumers who are active as co-producers. For example, KeyNest and GuestReady provide services to Airbnb hosts to manage co-production activities such as handing over the property key and cleaning the rental property. In the experience step, firms' support services are less central, since this step focuses on the consumption experience itself, but firms can still promote consumer learning to enhance the utility that co-producers and their consumers extract from the co-production experience. In this spirit, Airbnb offers online guidance to hosts on how to create a great experience not only in their home but also around the neighborhood as part of their guests' visits. In the reflect step, consumer co-production activities are supported similarly as in the search stage and firms offer easy-to-use online support to consumers who wish to actively provide evaluations to other consumers.

\section{Increasing consumers' monetary budget in co-production activities}

Finally, with respect to consumers' monetary budget, there are also opportunities for new marketing roles. Traditionally, in the consumption context, marketing has emphasized the role of pricing as a way to increase consumer value. For example, discounting and promotions allow consumers to lower the costs per product and hence spend their money on a greater number of products, which increases their overall utility. Marketing can push for more efficient production processes to lower costs, thereby creating room for price reductions. This has notably occurred in many manufacturing domains over the past few decades and new digital technologies are likely to extend this trend as they further reduce the cost of production.

In consumer co-production processes, consumers can also benefit from lower prices in the purchase step with respect to the products they buy. However, there is a different additional role for marketing in co-production that is not to negotiate lower prices on behalf of the consumer but, rather, to increase consumer income from co-production activities. Assisting consumers in increasing their co-production income can help them overcome two main income-generating challenges in their co-production role. First, many consumers have a relative lack of experience in commercializing (the outcomes of) their co-production activities and, second, consumers as coproducers have a relatively weak position in the labor market. Both issues lower their capacity to receive financial compensation for their co-production activities. 
This new marketing role is relevant to each of the four consumer production journey steps. In the search step, consumers can receive payment for sharing their ideas about product improvements, such as in crowdsourcing initiatives (Bayus 2013; Kleemann et al. 2008). When they act as distributors in the purchase step, consumers can be paid directly by other consumers and firms can facilitate this process by lowering the expense of the payment services. In the experience step, consumers can be paid for shared activities, such as when they rent out their apartment on websites such as Airbnb (Fraiberger and Sundararajan 2017). In the reflect step, consumers can receive financial compensation for communicating about their consumption experiences on social media (Bertini and Aydinli 2018).

The importance of this monetary aspect is further reflected in criticisms of co-production that highlight the fact that consumer co-production can be thought of as labor for which consumers are undercompensated in relation to its profitgenerating potential for firms (Cova and Dalli 2009; Ritzer and Jurgenson 2010). For example, drivers for firms such as Uber and Deliveroo have complained about payment and contract terms that provide relatively little job security compared to traditional jobs. In response, a new competitor named Fasten has responded to this dissatisfaction by actively promoting a more attractive (flat-fee) payment model for drivers. This latter market response illustrates the new marketing perspective of targeting consumers as co-producers in terms of their monetary budget by increasing consumer income from co-production.

\section{Marketing to consumers as co-producers: the network-level perspective}

Marketing can also support consumers at the network level, where multiple consumers collaborate in a consumer coproduction network. These marketing activities can increase consumers' joint payoff and assist them collectively in switching toward co-production-based value creation.

\section{Increasing consumers' joint payoff}

One important way to increase collective value in a consumer co-production network is by integrating and combining data across all individual consumer production journeys in the network. Each individual consumer has access to only very limited information about consumer demand and supply in the network, whereas platforms on which co-production exchanges take place are able to collect and analyze such data across all consumers (Sridhar et al. 2011; Wu 2015). Largescale data handling and analytics can provide additional value for consumers if shared by marketers across the network and can assist consumers in gaining greater utility and lowering their (labor and monetary) costs as co-producers. For example, supply and demand models for transportation or accommodation can assist consumers in deciding when to become active as co-producers, thus reducing their labor time and increasing their monetary returns.

Provided that there is a net gain from co-production in the network (see the next section, on consumer welfare effects, for potential limiting conditions), then a second way for marketing to increase consumers' joint payoff at the network level is by encouraging them to become more active as contributors in the consumer co-production network ( $\mathrm{Chu}$ and Manchanda 2016; Stephen and Toubia 2010). Within a consumer coproduction network, a higher level of consumer coproduction activity will create greater utility for the total network (compared to when fewer consumers contribute). Therefore, greater activity will benefit the collective of consumers in the network. For example, increased co-production can lead to a wider range of different products in the market for consumers to choose from if the products that are being designed or produced by consumers also become generally available for other consumers (Zervas et al. 2017). The latter then allows consumers to find products that more closely match their needs.

Marketing can further assist consumers by lowering the costs of co-production at the network level because certain costs are more efficiently borne at the network level than at the individual level. Typical instances of such network-level costs include collective communications (e.g., branding and advertising), collective insurance across all consumers in the network, and other collective services, such as information technology systems, whose costs can be shared across the network. Marketing can also help overcome the costs related to some of the potential darker sides of consumer coproduction at the network level. Firms can assist coproducing consumers collectively by establishing clear and fair rules of engagement. Such rules can help consumers as co-producers (by avoiding unfair market practices), as well as increase consumer confidence for those purchasing in online marketplaces. For example, in markets such as transportation or hospitality, traditionally well-established legal regulations exist to protect consumer rights and safeguard product quality, but these types of regulations are much less well established for co-production in these markets (compare taxis with Uber and hotels with Airbnb). Marketing functions that are particularly helpful in overcoming this difficulty are those that allow consumers to make more informed decisions about the quality of products and co-production activities in the market (Telles 2016). Firms can develop mechanisms to build co-producer reputations (such as peer review systems) and to exclude poorly performing coproducers from the market, which can be particularly helpful to consumers (Biglaiser and Friedman 1994). 


\section{Increasing consumers' reallocation and switchover feasibility}

Two feasibility conditions are important qualifiers for the joint payoff logic of a marketing design at the network level: reallocation feasibility and switchover feasibility (Carson et al. 1999). Reallocation feasibility implies that, in case not all agents in a value system benefit from switching to a new more efficient marketing design, an institutional arrangement that sufficiently compensates those agents who lose out in the transition must be feasible within the system. Such compensation is necessary to persuade agents to switch to the new marketing design. For example, consumers who do not enjoy sharing their car with strangers on BlaBlaCar may not be willing to do so unless they are compensated (monetarily or otherwise). If this compensation is not feasible (e.g., due to high quality uncertainty), the new marketing design will not succeed.

Switchover feasibility implies that path dependence and switching costs to transition from an existing marketing design to the new design must be sufficiently low so that they can be overcome by the benefits of the new marketing design. For example, for a new car sharing system to be attractive, some consumers may need to purchase new or different types of cars to be attractive as drivers to other consumers and to generate a sufficient number of car-sharing opportunities in the system for it to be feasible. To meet these conditions, the design of an institutional arrangement, such as new legal arrangements, must be feasible that allows individual consumers (as passengers and as drivers) to switch to the new system.

One supply challenge related to the reallocation of value in the context of consumer co-production is the fact that consumer knowledge and expertise are often tacit, which implies that consumers' (potential) contributions are hard to measure or value before they are actually implemented (Spann et al. 2009). This valuation challenge increases uncertainty for consumers and firms and makes it difficult to trade consumer coproduction activities upfront with an aim to stimulate consumers into becoming co-producers. It is hard for other consumers and firms to know what the value of a co-producing consumer's actions will be and to contract on a payment for consumer co-production (Henkel et al. 2013). This uncertainty can restrict consumers' and firms' willingness to engage in coproduction. Firms can promote the modularization of production tasks within a network level to overcome this challenge because it allows for trading to take place at a less risky the module level within a larger platform structure. In such a flexible, modularized structure, selective more well-defined tasks can be co-produced by consumers while other tasks can be offered by the firm (Baldwin 2007).

On the demand side, consumers' preferences are often uncertain and hard to predict, even for the consumers themselves (Simonson 2005). This unpredictability implies that consumer purchase decisions can be more difficult than in a traditional marketing process, where consumers can typically make decisions between finished products (Syam et al. 2008). Predictive analytics can be used as a basis for marketing activities such as recommendation and matching systems that help consumers develop insights into their own and others' future needs and hence lower the costs and risks of finding a match between co-production activities and consumer demand (Telles 2016). Early commitment mechanisms can also help by providing specific pricing structures and process designs that guarantee consumer buy-in earlier in the process than is traditionally the case (Ogawa and Piller 2006).

There are also challenges and costs related to valuing and pricing co-production activities. These are especially relevant in case consumer co-production requires value redistribution across the network. As in traditional markets where specialization occurs, different agents in consumer co-production networks will take on different roles and not all value creation activities may be equally valuable. Therefore, reallocation between consumers may be necessary and marketing functions that involve consumer reward mechanisms can be introduced to achieve this goal. These mechanisms can be based on payments, but other types of personal recognition (e.g., community status symbols) are also important (Mathwick and Mosteller 2017).

When we turn to switchover feasibility, one further aspect stands out, which is the fact that current market and legal structures can be challenged by co-production network structures (Lobel 2017). In many markets, such as transportation, hospitality, and health, there are strict regulations and traditions on how services need to be provided. It is difficult and costly for individual consumers to overcome legal restrictions and social norms that restrict consumer co-production activities. Marketing functions at the consumer co-production network level can take on lobbying and legal services that can benefit individual consumers in terms of being (legally) allowed to participate in the co-production process.

\section{Conclusion and discussion}

In the sharing economy, consumers act as co-producers by creating value for other consumers with whom they engage on online platforms (Frenken and Schor 2017; Narasimhan et al. 2018; Sundararajan 2016; Telles 2016). This paper proposed a new two-layered framework to systematically analyze marketing's potential role in this new market structure, in particular, to investigate ways in which marketing can create value for consumers who are themselves also co-producers. We first introduced consumer co-production networks as value creation systems in which consumers and firms work together and, next, the individual consumer production journey to allow for a more detailed analysis of consumer co- 
production activities within these networks. Building on household production theory, consumer behavior research, and institutional design theory we then provided specific suggestions on how marketing can increase consumer value at both levels of analysis in a consumer co-production network.

\section{Managerial implications}

Consumer co-production networks present challenges for traditional marketing but also new opportunities for consumerbased strategies. Firms may need to target different consumer activities and different consumers and focus on different marketing resources than they have traditionally done to create a new sustainable strategic advantage (Priem 2007; Wernerfelt 2014). Three focal areas of activity stand out through which marketing can support consumers who are co-producers at the individual level: (1) generation of greater utility from the consumer co-production process itself (e.g., by increasing the enjoyment of co-production), (2) lowering of consumers' coproduction efforts, also by increasing consumer co-production skills (e.g., by offering training and production convenience), and (3) increasing the consumer's income from co-production (e.g., by helping consumers commercialize their coproduction efforts). At the level of consumer co-production networks, marketing can also undertake activities to support consumer co-production. They can be classified in two broad categories: (1) offering consumers collective co-production services that are less costly to provide at the network level than at the individual (e.g., by providing matching algorithms, network-level branding, collective insurances, and legal support) and (2) establishing clear rules of engagement regarding market behavior within the network, including support for an equitable redistribution of network-level income between consumers and between consumers and firms (e.g., by providing consumer co-production quality measures, reward mechanisms, and regulation).

Like consumers who are becoming co-producers, firms also need to trade off the costs and benefits of participating in consumer co-production networks and, if they do, determine the most cost-effective ways of assisting co-producing consumers. Different marketing activities are not equally impactful in assisting consumers and the costs of these activities also differ. Firms can benefit from consumer co-production in various ways. For example, firms can commercialize the focused consumer attention that co-production generates by attracting advertising to those consumers, or they can take a percentage of the income that is generated by consumers who are coproducers (Lambrecht et al. 2014; Matzler et al. 2015; Sundararajan 2016). However, these potential gains can be reduced by additional costs. Therefore, firms need to carefully consider which marketing activities create the greatest additional value for consumers and if these activities can be provided at a positive net return for the firm. For example, developing an online matching system is a costly upfront investment, but one that is likely to be necessary to support a successful consumer co-production network (Telles 2016). However, the need to invest in branding and advertising can be more gradual and can be scaled up as the consumer coproduction network grows.

The growing importance of consumer co-production also implies that firms' consumer valuation models need to be extended to capture a wider range of consumer activities. Although recently the literature on consumer engagement has proposed extensions of earlier consumer valuation models to include such aspects as social media activities and word of mouth (Kumar et al. 2010), our analysis shows that, in all four steps of the consumer production journey, consumers can provide valuable contributions to other consumers' utility. Thus, we propose that consumer lifetime models should be expanded to also capture those different contributions. For example, in the search step, consumers can contribute by providing recommendations to other consumers and, in the purchase step, they can contribute by participating in the sales and distribution of products. This updated consumer valuation model then also has implications for firm valuation models, since the value of a firm's customer base driven by the co-production activities of its customers becomes an important component of the total firm value. This newly proposed approach is similar in spirit to recent research that aims to quantify the employee base as part of a firm's overall valuation (Fulmer and Ployhart 2014).

At a more strategic level, a potential strategic marketing resource for firms operating in consumer co-production networks is firms' effective leverage of (big) data through advanced analytics to provide consumers with insights and support. Consumer and market data skills and analytics have a strong multiplier effect. Developing insights from the collective of consumers is a particularly powerful way for firms to generate knowledge that each individual consumer finds hard to obtain. It is difficult for each separate individual to review the entire market and what other consumers do. Firms that can empower and support consumers as co-production partners by using advanced analytics are ideally placed to generate and then share market-level insights with the community (Chung et al. 2016). The same data analytics skills should also be helpful for firms to identify, for each consumer production journey step, which consumers are most valuable in terms of creating value for other consumers. These consumers can be targeted with specific marketing actions and services to facilitate and enhance their co-production activities. In terms of data analytics, firms that can position themselves at the center of consumer co-production networks are likely to be the most successful. These firms have the greatest access to data regarding the network's activities and are therefore able to provide the most valuable insights based on data analytics (Evans and Schmalensee 2016). 
However, the use of information technology and consumer analytics also has inherent boundaries that restrict their potential to create value for consumers. Even the best-run analyses can result in flawed predictions when only scant consumer data are available or when consumption is highly unpredictable (Simonson 2005). Furthermore, co-producing consumers may not be interested in obtaining a firm's assistance to begin with, for example because they do not trust the firm's intentions to help. Thus, even if a firm's analysis is technically correct, its resulting recommendations and marketing actions may not reach the consumer unless this consumer is willing to actively engage with the firm.

Therefore, a second potential strategic marketing resource for firms in consumer co-production networks is their ability to activate and engage consumers in the value creation process (Atakan et al. 2014; Haumann et al. 2015; Ranjan and Read 2016). Such consumer activation is especially important for firms in markets with highly heterogeneous and fluid consumer needs, where consumers could quickly change their preferences over time and across contexts and easily switch between firms. Firms that achieve a high level of consumer activation and engagement so that these consumers become value creators using the firm's goods and services have a much greater potential to then also leverage the active consumer input in the value creation process to the benefit of other consumers. Creating co-production environments that are attractive to consumers and that promote transformational learning can help engage consumers in the co-production process (Pine and Gilmore 1998; Schmitt 2011). Furthermore, collective marketing services, such as the provision of matching algorithms, insurance, and legal services to support consumers who are co-producers, and the establishment of clear rules about operations and reallocations within the consumer coproduction network should help increase the active participation of co-producing consumers.

\section{Consumer welfare implications}

The recent growth in sharing economy-type firms suggests that consumer co-production networks can offer sustainable economic benefits over other types of marketing value chains, at least in some industries (Kathan et al. 2016; Lamberton and Rose 2012; Sundararajan 2016). However, relatively little is known about the extent to which these networks are consumer welfare enhancing compared to traditional marketing value system designs. While in this paper we are primarily concerned with the question of how marketing can create value for consumers, given the existence of consumer co-production networks, it is also worth briefly discussing this other more general question.

On the positive side, consumer co-production networks can create greater increase consumer welfare compared to traditional value chains when they lead to a better matching of supply and demand. They allow for more and more diverse products to be offered in the market, which benefits consumers in their roles as both buyers and sellers. This increased flexibility and diversity can lead to a more efficient allocation of assets and resources across consumers. Consumers can enjoy the co-production activities they undertake in their own right as well. In addition, there are potential monetary consumer benefits related to the commercialization of previously noncommercialized consumer activities. If consumers are empowered to commercialize the activities that they previously undertook for free, this shift can create new income streams for them.

On the negative side, there also clearly are potential consumer costs related to consumer co-production networks that can lower consumer welfare compared to traditional supply chains. At the individual journey level, consumers face costs related to the additional effort they need to exert when they become active as co-producers (e.g., driving a passenger to another location with Uber) and the need to invest in newer or higher-quality capital goods if they become active as coproducers (e.g., purchasing a newer car to be allowed to work through Uber). At the network level, consumer costs include the price they need to pay for various services that firms provide, such as information technology infrastructure, branding, and marketing communications. Consumers also face less tangible costs associated with co-production networks such as coordination and complexity costs are related to having to collaborate with many different agents in the network.

Not surprisingly, there is considerable debate on whether consumers are sufficiently compensated for their role as coproducers by online platform firms (Cova and Dalli 2009; Ritzer and Jurgenson 2010). What consumers gain in utility in their consumption (through greater access to more attractive co-produced services), they could lose in their labor activities (by being compensated less for their co-production activities than for their traditional labor). Firms are also emphasizing the enjoyment and excitement of co-production activities to increase consumer co-production activities (e.g., Uber has been criticized for developing a "game-like" interactive environment to entice drivers to complete more rides). However, in hindsight, consumers could regret the amount of time they spent on these activities. While research has shown that consumers tend to view the consumption of co-production activities from a rather utilitarian perspective (Eckhardt and Bardhi 2015), it is still less clear how they view their production of such activities.

The greater degree of commercialization of what were traditionally informal activities for family and friends in itself can also lower consumers' valuation of these activities. Monetizing interactions that were earlier seen as acts of kindness or friendship can lower consumers' appreciation of these interactions and increase stress (Gasiorowska et al. 2016; Lobel 2017). The co-production value creation process also 
places greater responsibility on consumers to manage their actions as economic assets. Giesler and Veresiu (2014) point to the fact that in their new role of "responsible" consumer, consumers are asked to approach their own health and finances mainly as economic assets for which they themselves are ultimately responsible, and that they have to manage responsibly. This responsibility and the greater uncertainty that it creates can also lower the utility consumers obtain from the process.

\section{Limitations and future research}

An inherent limitation of a conceptual analysis such as this paper's is that empirical support for the proposed theorizing is provided only indirectly by findings in the literature and by way of examples. Therefore, it would be interesting and relevant to test (sections of) the proposed relations and structures in subsequent empirical research. In particular, the real-world effectiveness of different marketing actions in the four steps of the consumer production journey or systemlevel interventions in consumer co-production networks could be evaluated.

It would also be worth studying possible moderating variables that could affect the impact of marketing actions to support consumer co-production. At the individual consumer level, the moderating effect of consumers' mindsets and perceptions in connection with consumption- versus productionoriented activities offer an especially promising avenue for further research. The literature on hedonic versus utilitarian consumption can perhaps serve as a starting point for such an analysis (Babin et al. 1994) and could be extended and adapted to capture the fact that, nowadays, consumers not only are consumers for utilitarian purposes (as opposed to hedonic purposes) but also have begun to produce for commercial markets and receive payments for their labor and products, which could influence their decisions (Gasiorowska et al. 2016). Recent research has begun to address a number of related topics in investigating what attracts different consumers to become active as co-producers and how this can differ between different contexts (Habibi et al. 2016; Martineau and Arsel 2017; Xie et al. 2008). At the network level, the potential supply of consumers who can be co-producers and of firms that offer competing services to the services that are being co-produced are likely to moderate the impact of the costs of labor and capital goods on co-coproduction activities. A greater supply (by either consumers or firms) will typically lead to lower prices and, hence, a weaker effect of the underlying costs on market transactions.

Future research could also develop a deeper and more detailed understanding of the network-level processes by which consumers co-produce value in commercial consumer markets. While there is a large literature on topics such as consumer (brand) communities (Muniz and O'Guinn 2002) there is still relatively little empirical research on how consumers collaborate as co-producers, both among themselves and with firms (Sundararajan 2016). A related, more general question is that of the most welfare-enhancing level of commercialization in consumer co-production settings. While the power of platforms such as Facebook, Airbnb, and Uber to generate change and commercialize consumer activities in today's markets is very clear (Sundararajan 2016), some argue there are new opportunities for collaborative consumption that are non-market based and which directly draw on voluntary exchanges between consumers (Rifkin 2014). It would be interesting to study such competing institutional designs empirically and to see the conditions under which the various models might prevail. An additional general institutional design question worth investigating is whether consumer coproduction over time can lead to greater monopolistic power for the platform firms that facilitate this type of production model most effectively (Langley and Leyshon 2017). Scale is likely to be an important driver of platform success, which could imply that, despite the greatly dispersed co-production process at the consumer level, the resulting market structure could still be highly concentrated at the firm level.

Finally, we hope that our analysis has highlighted the relevance of rethinking the role of marketing in new value creation systems where consumers become value producers in their own right. With the growth of the sharing economy, pressure is increasing on firms' traditional marketing functions, but there are also many new opportunities for consumer-based strategies that focus on supporting consumers in their new role. Firms that can assist and activate consumers in creating value for other consumers through a mix of "hard" analytics and "soft" engagement -based marketing resources are likely to be well placed to be successful in the new emerging market structures that rely on consumer co-production.

Acknowledgements The author thanks Nuno Camacho, Stefano Puntoni, Roland Rust, Dimitrios Tsekouras, Sonja Wendel, and participants at the JAMS Thought Leaders Conference, May 20-21, 2017, for valuable comments and suggestions on earlier versions of this paper. ERIM and Netspar provided grants to support part of this research.

Open Access This article is distributed under the terms of the Creative Commons Attribution 4.0 International License (http:// creativecommons.org/licenses/by/4.0/), which permits unrestricted use, distribution, and reproduction in any medium, provided you give appropriate credit to the original author(s) and the source, provide a link to the Creative Commons license, and indicate if changes were made.

\section{References}

Achrol, R. S., \& Kotler, P. (2012). Frontiers of the marketing paradigm in the third millennium. Journal of the Academy of Marketing Science, $40(1), 35-52$. 
Acquisti, A., Taylor, C., \& Wagman, L. (2016). The economics of privacy. Journal of Economic Literature, 54(2), 442-492.

Anderl, E., Becker, I., von Wangenheim, F. F., \& Schumann, J. H. (2016). Mapping the customer journey: Lessons learned from graph-based online attribution modeling. International Journal of Research in Marketing, 33(3), 457-474.

Atakan, S. S., Bagozzi, R. P., \& Yoon, C. (2014). Consumer participation in the design and realization stages of production: How self-production shapes consumer evaluations and relationships to products. International Journal of Research in Marketing, 31(4), 395-408.

Babin, B. J., Darden, W. R., \& Griffin, M. (1994). Work and/or fun: Measuring hedonic and utilitarian shopping value. Journal of Consumer Research, 20(4), 644-656.

Baldwin, C. Y. (2007). Where do transactions come from? Modularity, transactions, and the boundaries of firms. Industrial and Corporate Change, 17(1), 155-195.

Bardhi, F., \& Eckhardt, G. M. (2012). Access-based consumption: The case of car sharing. Journal of Consumer Research, 39(4), 881-898.

Bayus, B. L. (2013). Crowdsourcing new product ideas over time: An analysis of the Dell IdeaStorm community. Management Science, 59(1), 226-244.

Becker, G. S. (1965). A theory of the allocation of time. Economic Journal, 75(299), 493-517.

Belk, R. (2007). Why not share rather than own? The Annals of the American Academy of Political and Social Science, 611(1), 126-140.

Belk, R. (2010). Sharing. Journal of Consumer Research, 36(5), 715734.

Benkler, Y. (2002). Coase's penguin, or, Linux and "the nature of the firm". The Yale Law Journal, 12(3), 369-446.

Bertini, M., \& Aydinli, A. (2018). Consumer reactance to conditional discounts. SSRN no. 2804455.

Betancourt, R., \& Gautschi, D. (1990). Demand complementarities, household production, and retail assortments. Marketing Science, 9(2), 146-161.

Biglaiser, G., \& Friedman, J. W. (1994). Middlemen as guarantors of quality. International Journal of Industrial Organization, 12(4), 509-531.

Bloom, N., Garicano, L., Sadun, R., \& van Reenen, J. (2014). The distinct effects of information technology and communication technology on firm organization. Management Science, 60(12), 2859-2885.

Botsman, R., \& Rogers, R. (2010). What's mine is yours: The rise of collaborative consumption. New York: HarperCollins.

Brodie, R. J., Ilic, A., Juric, B., \& Hollebeek, L. (2013). Consumer engagement in a virtual brand community: An exploratory analysis. Journal of Business Research, 66(1), 105-114.

Bronnenberg, B. J. (2015). The provision of convenience and variety by the market. RAND Journal of Economics, 46(3), 480-498.

Brynjolfsson, E., \& McAfee, A. (2014). The second machine age: Work, progress, and prosperity in a time of brilliant technologies. New York: W.W. Norton.

Buechel, E. C., \& Janiszewski, C. (2014). A lot of work or a work of art: How the structure of a customized assembly task determines the utility derived from assembly effort. Journal of Consumer Research, 40(5), 960-972.

Carson, S. J., Devinney, T. M., Dowling, G. R., \& John, G. (1999). Understanding institutional designs within marketing value systems. Journal of Marketing, 63(4), 115-130.

Chu, J., \& Manchanda, P. (2016). Quantifying cross and direct network effects in online consumer-to-consumer platforms. Marketing Science, 35(6), 870-893.

Chung, T. S., Wedel, M., \& Rust, R. T. (2016). Adaptive personalization using social networks. Journal of the Academy of Marketing Science, 44(1), 66-87.
Cova, B., \& Dalli, D. (2009). Working consumers: The next step in marketing theory? Marketing Theory, 9(3), 315-339.

Da, Z., Yang, W., \& Yun, H. (2015). Household production and asset prices. Management Science, 62(2), 387-409.

Dellaert, B. G. C., \& Stremersch, S. (2005). Marketing mass-customized products: Striking a balance between utility and complexity. Journal of Marketing Research, 42(2), 219-227.

Eckhardt, G. M., \& Bardhi, F. (2015). The sharing economy isn't about sharing at all. Harvard Business Review Retrieved from https://hbr. org/2015/01/the-sharing-economy-isnt-about-sharing-at-all.

Etgar, M. (2008). A descriptive model of the consumer coproduction process. Journal of the Academy of Marketing Science, 36(1), 97-108.

Evans, B. J. (2017). Barbarians at the gate: Consumer-driven health data commons and the transformation of citizen science. American Journal of Law \& Medicine, 42(4), 651-685.

Evans, D. S., \& Schmalensee, R. (2016). Matchmakers: The new economics of multisided platforms. Boston: Harvard Business Review Press.

Fraiberger, S. P., \& Sundararajan, A. (2017). Peer-to-peer rental markets in the sharing economy. NYU Stern School of Business research paper. Available at SSRN, https://ssrn.com/abstract $=2574337$.

Franke, N., \& Piller, F. (2004). Value creation by toolkits for user innovation and design: The case of the watch market. Journal of Product Innovation Management, 21(6), 401-415.

Franke, N., von Hippel, E., \& Schreier, M. (2006). Finding commercially attractive user innovations: A test of lead-user theory. Journal of Product Innovation Management, 23(4), 301-315.

Franke, N., Schreier, M., \& Kaiser, U. (2010). The "I designed it myself" effect in mass customization. Management Science, 56(1), 125-140.

Frenken, K., \& Schor, J. (2017). Putting the sharing economy into perspective. Environmental Innovation and Societal Transitions, 23, 3-10.

Fuchs, C., Prandelli, E., \& Schreier, M. (2010). The psychological effects of empowerment strategies on consumers' product demand. Journal of Marketing, 74(1), 65-79.

Fulmer, I. S., \& Ployhart, R. E. (2014). Our most important asset. A multidisciplinary/multilevel review of human capital valuation for research and practice. Journal of Management, 40(1), 161-192.

Gansky, L. (2010). The mesh: Why the future of business is sharing. New York: Portfolio Penguin.

Gasiorowska, A., Chaplin, L. N., Zaleskiewicz, T., Wygrab, S., \& Vohs, K. D. (2016). Money cues increase agency and decrease prosociality among children: Early signs of market-mode behaviors. Psychological Science, 27(3), 331-344.

Giesler, M., \& Veresiu, E. (2014). Creating the responsible consumer: Moralistic governance regimes and consumer subjectivity. Journal of Consumer Research, 41(3), 840-857.

Goldfarb, A., \& Tucker, C. E. (2011). Privacy regulation and online advertising. Management Science, 57(1), 57-71.

Greenwood, J., Seshadri, A., \& Yorukoglu, M. (2005). Engines of liberation. Review of Economic Studies, 72(1), 109-133.

Grönroos, C., \& Voima, P. (2013). Critical service logic: Making sense of value creation and co-creation. Journal of the Academy of Marketing Science, 41(2), 133-150.

Habibi, M. R., Kim, A., \& Laroche, M. (2016). From sharing to exchange: An extended framework of dual modes of collaborative nonownership consumption. Journal of the Association for Consumer Research, 1(2), 277-294.

Hamari, J., Sjöklint, M., \& Ukkonen, A. (2016). The sharing economy: Why people participate in collaborative consumption. Journal of the Association for Information Science and Technology, 67(9), 2047-2059.

Hamilton, R. (2016). Consumer-based strategy: Using multiple methods to generate consumer insights that inform strategy. Journal of the Academy of Marketing Science, 44(3), 281-285. 
Haumann, T., Güntürkün, P., Schons, L. M., \& Wieseke, J. (2015). Engaging customers in coproduction processes: How valueenhancing and intensity-reducing communication strategies mitigate the negative effects of coproduction intensity. Journal of Marketing, 79(6), 17-33.

Henkel, J., Baldwin, C. Y., \& Shih, W. (2013). IP modularity: Profiting from innovation by aligning product architecture with intellectual property. California Management Review, 55(4), 65-82.

Hildebrand, C., Häubl, G., \& Herrmann, A. (2014). Product customization via starting solutions. Journal of Marketing Research, 51(6), 707-725.

Humphreys, A., \& Grayson, K. (2008). The intersecting roles of consumer and producer: A critical perspective on co-production, co-creation and prosumption. Sociology Compass, 2(3), 963-980.

Hunt, S. D., \& Morgan, R. M. (1995). The comparative advantage theory of competition. Journal of Marketing, 59(2), 1-15.

Jiang, B., \& Tian L. (2016). Collaborative consumption: Strategic and economic implications of product sharing. Management Science, articles in advance. https://doi.org/10.1287/mnsc.2016.2647, 64, 1171,1188

John, D. R. (1999). Consumer socialization of children: A retrospective look at twenty-five years of research. Journal of Consumer Research, 26(3), 183-213.

Kathan, W., Matzler, K., \& Veider, V. (2016). The sharing economy: Your business model's friend or foe? Business Horizons, 59(6), 663-672.

Kleemann, F., Voss, G. G., \& Rieder, K. (2008). Un(der) paid innovators: The commercial utilization of consumer work through crowdsourcing. Science, Technology \& Innovation Studies, 4(1), 5-26.

Kozlenkova, I. V., Samaha, S. A., \& Palmatier, R. W. (2014). Resourcebased theory in marketing. Journal of the Academy of Marketing Science, 42(1), 1-21.

Kumar, V., Aksoy, L., Donkers, B., Venkatesan, R., Wiesel, T., \& Tillmanns, S. (2010). Undervalued or overvalued customers: Capturing total customer engagement value. Journal of Service Research, 13(3), 297-310.

Kumar, V., Dixit, A., Javalgi, R. G., \& Dass, M. (2016). Research framework, strategies, and applications of intelligent agent technologies (IATs) in marketing. Journal of the Academy of Marketing Science, 44(1), 24-45.

Labrecque, L. I., vor dem Esche, J., Mathwick, C., Novak, T. P., \& Hofacker, C. F. (2013). Consumer power: Evolution in the digital age. Journal of Interactive Marketing, 27(4), 257-269.

Lamberton, C. P., \& Rose, R. L. (2012). When is ours better than mine? A framework for understanding and altering participation in commercial sharing systems. Journal of Marketing, 76(4), 109-125.

Lambrecht, A., Goldfarb, A., Bonatti, A., Ghose, A., Goldstein, D. G., Lewis, R., Rao, A., Sahni, N., \& Yao, S. (2014). How do firms make money selling digital goods online? Marketing Letters, 25(3), 331-341.

Lancaster, K. J. (1966). A new approach to consumer theory. Journal of Political Economy, 74(2), 132-157.

Langley, P., \& Leyshon, A. (2017). Platform capitalism: The intermediation and capitalisation of digital economic circulation. Finance and Society, 3(1), 11-31.

Li, H. A., \& Kannan, P. K. (2014). Attributing conversions in a multichannel online marketing environment: An empirical model and a field experiment. Journal of Marketing Research, 51(1), 40-56.

Lobel, O. (2017). The gig economy \& the future of employment and labor law. University of San Francisco Law Review, 51, 51-74.

Luo, L., Ratchford, B. T., \& Yang, B. (2013). Why we do what we do: A model of activity consumption. Journal of Marketing Research, 50(1), 24-43.

Lusch, R. F., \& Nambisan, S. (2015). Service innovation: A servicedominant logic perspective. MIS Quarterly, 39(1), 155-175.
Martineau, E., \& Arsel, Z. (2017). Managing communities of co-creation around consumer engagement styles. Journal of the Association for Consumer Research, 2(2), 179-195.

Mathwick, C., \& Mosteller, J. (2017). Online reviewer engagement: A typology based on reviewer motivations. Journal of Service Research, 20(2), 204-218.

Mathwick, C., Wiertz, C., \& De Ruyter, K. (2008). Social capital production in a virtual P3 community. Journal of Consumer Research, 34(6), 832-849.

Matzler, K., Veider, V., \& Kathan, W. (2015). Adapting to the sharing economy. MIT Sloan Management Review, 56(2), 71-77.

McAfee, A., \& Brynjolfsson, E. (2017). Machine, platform, crowd: Harnessing our digital future. New York: W.W. Norton.

Mochon, D., Norton, M. I., \& Ariely, D. (2012). Bolstering and restoring feelings of competence via the IKEA effect. International Journal of Research in Marketing, 29(4), 363-369.

Muniz, A. M., \& O'Guinn, T. C. (2002). Brand community. Journal of Consumer Research, 27(4), 412-432.

Muniz, A. M., \& Schau, H. J. (2011). How to inspire value-laden collaborative consumer-generated content. Business Horizons, 54(3), 209-217.

Muth, R. F. (1966). Household production and consumer demand functions. Econometrica, 34(3), 699-708.

Narasimhan, C., Papatla, P., Jiang, B., Kopalle, P. K., Messinger, P. R., Moorthy, S., Proserpio, D., Subramanian, U., Wu, C., \& Zhu, T. (2018). Sharing economy: Review of current research and future directions. Customer Needs and Solutions, 5(1-2), 93-106.

Norton, D. W., \& Pine, B. J. (2013). Using the customer journey to road test and refine the business model. Strategy \& Leadership, 41(2), $12-17$.

Ogawa, S., \& Piller, F. T. (2006). Reducing the risks of new product development. MIT Sloan Management Review, 47(2), 65-71.

Payne, A. F., Storbacka, K., \& Frow, P. (2008). Managing the cocreation of value. Journal of the Academy of Marketing Science, 36(1), 83-96.

Pine, B. J., \& Gilmore, J. H. (1998). Welcome to the experience economy. Harvard Business Review, 76(4), 97-105.

Piskorski, M. J. (2011). Social strategies that work. Harvard Business Review, 89(11), 116-122.

Prahalad, C. K., \& Ramaswamy, V. (2004). Co-creation experiences: The next practice in value creation. Journal of Interactive Marketing, $18(3), 5-14$.

Priem, R. L. (2007). A consumer perspective on value creation. Academy of Management Review, 32(1), 219-235.

Ranjan, K. R., \& Read, S. (2016). Value co-creation: Concept and measurement. Journal of the Academy of Marketing Science, 44(3), 290-315.

Ratchford, B. T. (2001). The economics of consumer knowledge. Journal of Consumer Research, 27(4), 397-411.

Rifkin, J. (2014). The zero marginal cost society: The internet of things, the collaborative commons, and the eclipse of capitalism. New York: St. Martin's Press.

Ritzer, G., \& Jurgenson, N. (2010). Production, consumption, prosumption: The nature of capitalism in the age of the digital "prosumer". Journal of Consumer Culture, 10(1), 13-36.

Rust, R. T., \& Huang, M. H. (2014). The service revolution and the transformation of marketing science. Marketing Science, 33(2), 206-221.

Scaraboto, D. (2015). Selling, sharing, and everything in between: The hybrid economies of collaborative networks. Journal of Consumer Research, 42(1), 152-176.

Schmitt, B. (2011). Experience marketing: Concepts, frameworks and consumer insights. Foundations and Trends in Marketing, 5(2), $55-112$. 
Schor, J. B., \& Attwood-Charles, W. (2017). The "sharing" economy: Labor, inequality, and social connection on for-profit platforms. Sociology Compass, 11(8), 1-16.

Simonson, I. (2005). Determinants of customers' responses to customized offers: Conceptual framework and research propositions. Journal of Marketing, 69(1), 32-45.

Simonson, I., \& Rosen, E. (2014). Absolute value: What really influences customers in the age of (nearly) perfect information. New York: Harper Collins.

Spann, M., Ernst, H., Skiera, B., \& Soll, J. H. (2009). Identification of lead users for consumer products via virtual stock markets. Journal of Product Innovation Management, 26(3), 322-335.

Sridhar, S., Mantrala, M. K., Naik, P. A., \& Thorson, E. (2011). Dynamic marketing budgeting for platform firms: Theory, evidence, and application. Journal of Marketing Research, 48(6), 929-943.

Stephen, A. T., \& Toubia, O. (2010). Deriving value from social commerce networks. Journal of Marketing Research, 47(2), 215-228.

Sundararajan, A. (2016). The sharing economy: The end of employment and the rise of crowd-based capitalism. Cambridge: MIT Press.

Syam, N., Krishnamurthy, P., \& Hess, J. D. (2008). That's what I thought I wanted? Miswanting and regret for a standard good in a masscustomized world. Marketing Science, 27(3), 379-397.

Telles, R., Jr. (2016). Digital matching firms: A new definition in the "sharing economy" space. ESA issue brief: 01-16.

Thaler, R. H., \& Tucker, W. (2013). Smarter information, smarter consumers. Harvard Business Review, 91(1), 44-54.

Thomas, T. C., Schau, H. J., \& Price, L. L. (2013). When differences unite: Resource dependence in heterogeneous consumption communities. Journal of Consumer Research, 39(5), 1010-1033.
Tucker, C. E. (2014). Social networks, personalized advertising, and privacy controls. Journal of Marketing Research, 51(5), 546-562.

Vargo, S. L., \& Lusch, R. F. (2016). Institutions and axioms: An extension and update of service-dominant logic. Journal of the Academy of Marketing Science, 44(1), 5-23.

Von Hippel, E. (1986) Lead Users: A Source of Novel Product Concepts. Management Science 32 (7):791-805

Von Hippel, E. (1994). "Sticky information" and the locus of problem solving: Implications for innovation. Management Science, 40(4), 429-439.

Wernerfelt, B. (1994). An efficiency criterion for marketing design. Journal of Marketing Research, 31(4), 462-470.

Wernerfelt, B. (2014). On the role of the RBV in marketing. Journal of the Academy of Marketing Science, 42(1), 22-23.

Wiesel, T., Pauwels, K., \& Arts, J. (2011). Practice prize paperMarketing's profit impact: Quantifying online and off-line funnel progression. Marketing Science, 30(4), 604-611.

Wirtz, D., Kruger, J., Scollon, C. N., \& Diener, E. (2003). What to do on spring break? The role of predicted, on-line, and remembered experience in future choice. Psychological Science, 14(5), 520-524.

$\mathrm{Wu}, \mathrm{C}$. (2015). Matching value and market design in online advertising networks: An empirical analysis. Marketing Science, 34(6), 906-921.

Xie, C., Bagozzi, R. P., \& Troye, S. V. (2008). Trying to prosume: Toward a theory of consumers as co-creators of value. Journal of the Academy of Marketing Science, 36(1), 109-122.

Zervas, G., Proserpio, D., \& Byers, J. W. (2017). The rise of the sharing economy: Estimating the impact of Airbnb on the hotel industry. Journal of Marketing Research, 54(5), 687-705. 